\title{
Um Exemplo de Identificação com os Ideais e Princípios da ABPol
}

A Associação Brasileira de Polímeros desde sua fundação se preocupou em manter um equilíbrio em todas as suas ações e interações. Com isso conseguiu um quadro de sócios que atuam tanto em universidades, centros de pesquisa e desenvolvimento como na indústria. Existe um equilibrio dos membros do Conselho Deliberativo da ABPol, dos membros da sua Diretoria e em diversas outras áreas. As atividades da ABPol também são igualmente voltadas aos diversos setores da área de polímeros visando manter esse equilíbrio. Os presidentes da ABPol foram eleitos pelo conselho, alternando ora um presidente pertencente a uma universidade ou a um centro de pesquisa e ora a uma indústria. Domingos Jafelice, presidente da ABPol nos últimos quatro anos, atua na indústria desde 1979 e tem formação e especialização na área de polímeros. Fez uma administração que merece todos os elogios dos sócios da entidade. Apesar de o estatuto da ABPol não permitir a sua eleição consecutiva pela terceira vez, podemos contar com ele na presidência em um futuro próximo. Aproveitamos esta oportunidade, em nome de toda nossa comunidade, para externar nossa gratidão ao Domingos Jafelice por tudo que ele fez em prol da ABPol e também registrar o quão foi prazerosa sua presença alegre e ativa em nossa associação como presidente. Abaixo transcrevemos a entrevista que o comitê editorial da revista preparou.

Domingos Jafelice, conte-nos resumidamente sua carreira profissional na área de Polímeros.

Iniciei minha carreira na DOW em 1979 - TS\&D - plásticos. Em 1982 transferi-me para a Arno onde fui chefe do laboratório de plásticos até 1984. Entre 1985 e 1996 trabalhei na Nitriflex como gerente comercial de plásticos e elastômeros. Em 1997 assumi a diretoria da DSM South America onde permaneci até 2002. Em 2003 assumi a diretoria comercial da Polietilenos União onde permaneço até a presente data.

Como você vê a perspectiva do crescimento do uso de polímeros no país e quais os pontos relevantes do desenvolvimento desta área.

Haverá forte crescimento no uso de polímeros no Brasil nos próximos 10 anos. O consumo de polímeros no Brasil não ultrapassa $30 \mathrm{~kg}$ per capita (dado de 2004) enquanto supera a casa dos 100 kg per capita em países mais desenvolvidos. O potencial de crescimento é muito grande. Fatores como aumento e distribuição de renda, crescimento da economia, investimentos em infra estrutura e novos pólos petro e gasquímicos e renovação do parque de máquinas de transformação serão determinantes no desenvolvimento nessa área.

\section{Como foi sua aproximação com} a ABPol?

Orgulho-me de ser sócio individual da ABPol desde o seu ano de fundação (1988). Senti plena identificação tanto com os ideais e princípios quanto com o grupo dos profissionais fundadores da ABPol desde o primeiro dia de existência da associação.

\section{O que o levou a se candidatar à presidência da ABPol e à reelei- ção para o cargo? \\ A intenção de contribuir de modo mais significativo com a associação e o setor dos polí- meros do Brasil e a inequívoca proje- ção profissional conferida pela po- sição.}$$
\text { (1) }
$$

Após 4 anos liderando a Associação Brasileira de Polímeros, qual seu balanço sobre a entidade e quais os principais avanços obtidos?

Tenho o prazer de afirmar que a
ABPol cresceu e se fortaleceu nos últimos 4 anos. $\mathrm{O}$ crescimento do CBPol, o auxílio à organização do PPS, do ISNAPOL e do Colóquio de Macromoléculas, os Seminários de Embalagem e dos Polímeros do Futuro, os cursos de treinamento "in company" e do convênio ABPol / UFSCar, as sessões "Café com Polímeros" organizadas pela Regional 
A ABPol é reconhecida mundialmente como uma entidade séria. No Brasil, perante as instituições financiadoras, as universidades, centros de pesquisa e desenvolvimento e as indústrias, a ABPol é uma entidade respeitada. Como você acredita que a entidade tenha atingido tal prestígio?

Prestígio e confiabilidade - fatores essenciais para a perenidade de qualquer associação - são conquistados (nunca impostos) com trabalho de longo prazo. $\mathrm{O}$ respeito que a $\mathrm{ABPol}$ hoje inspira foi construído pela dedicação de todas as diretorias que administraram a associação e de todos os parceiros que a apoiaram desde a sua fundação.

Na ABPol tornaram-se tradições atividades como CBPol (Congresso Brasileiro de Polímeros), as reuniões de Comissões Técnicas, a revista "Polímeros: Ciência e Tecnologia". O que as mantêm tão sólidas e atraentes junto aos sócios?

A ABPol teve, em seus quase 18 anos de existência, a habilidade de manter suas atividades e eventos sempre alinhados ao grande dinamismo do setor de polímeros do Brasil. Além da responsabilidade da constante atualização, a $\mathrm{ABPol}$ assumiu em várias oportunidades o papel de precursor e indutor das tendências (como ocorreu ao organizar o seminário dos polímeros do futuro em 2002) o que contribui para reforçar a importância das suas atividades.

\section{Dê sua opinião sobre a Revista}

Tenho a satisfação de dizer que a revista "Polímeros: Ciência e Tecnologia" foi um dos pontos de maior evolução da ABPol nos últimos cinco anos. Ao lado do site na Internet, das participações em feiras e exposições e dos cursos e seminários, a revista tem papel fundamental na exposição e visibilidade da ABPol, na divulgação de trabalhos científicos e das notícias que impactam as corporações e instituições do setor de polímeros do Brasil. A revista, em última análise, por "mostrar a cara" da associação, contribui de modo determinante na construção da sua reputação e da sua imagem.

A ABPol tem sócios Individuais, Juniores, Coletivos e Patrocinadores. Como está esse quadro de sócios da entidade? É o que se esperaria?

O quadro de associados, após a crise de 2001, mostra crescimento constante ano após ano. O ponto mais importante e saudável, porém, é que o perfil dos sócios está mais equilibrado, pois o número de membros individuais e juniores - que não tem peso financeiro expressivo nas contribuições, mas que representa o futuro acervo de professores, executivos, pesquisadores e cientistas do setor de polímeros do Brasil cresceu muito nos últimos dois anos. A expectativa é que essa tendência perdure por mais alguns anos para que o quadro de sócios da ABPol possa refletir a pirâmide social dos profissionais do setor de polímeros do Brasil.

Como você vê ou gostaria de ver a ABPol no futuro próximo?

Minha visão de futuro é de uma ABPol global, integrada com associações similares em todo o mundo, com presença em eventos internacionais e ação em todas as regiões economicamente importantes do Brasil. A revista e o site na Internet da ABPol do futuro será, no mínimo, bilíngüe.

Quais são seus planos de atuação junto à ABPol para of futuro?

Meu plano é permanecer sempre à disposição da ABPol para poder contribuir para o fortalecimento da associação. "Passarei o bastão" da presidência ao meu sucessor mas estarei sempre próximo e pronto para apoiá-lo.

Deixe-nos uma mensagem final.

Presidir a ABPol por duas gestões sucessivas foi ao mesmo tempo uma honra e um prazer para mim. $\mathrm{O}$ apoio das diretorias, dos patrocinadores, da secretaria, das entidades de fomento e dos parceiros e colaboradores da associação foram fatores essenciais para o cumprimento das metas definidas desde o primeiro dia da minha administração. Desejo ao meu sucessor a mesma sorte que tive e coloco-me à disposição para continuar atuando em prol da associação. 